\title{
Application of ion-exchange resins for removing sulphate ions from acidic solutions
}

\author{
M. Holub \\ Laboratory of Excellent Research, Faculty of Civil Engineering, Technical University of Kosice \\ Park Komenskeho 10A, 04200 Kosice, Slovakia \\ E-mail: marian.holub@tuke.sk \\ P. Pavlikova, M. Balintova, M. Smolakova \\ Institute of Environmental Engineering, Faculty of Civil Engineering, Technical University of \\ Kosice \\ Vysokoskolska 4, 04200 Kosice, Slovakia

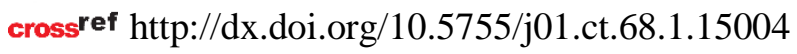

Received 17 May 2016; Accepted 04 April 2017

The removal of sulphate ions from different types of wastewater is an environmental challenge faced by several industrial sectors such as the mining, petrochemical or metallurgical industry. Most of the current existing options are inefficient and economically unviable, particularly for acid mine drainage (AMD), where the low $\mathrm{pH}$ and high concentrations of heavy metals and sulphates are limiting for these processes. This work is focused on ionexchange as one of the most common treatment methods for AMD treatment.

Ion-exchange represents a very powerful technology where one or more undesirable contaminants are removed from the aqueous environment by exchange with another substance. The ideal ion-exchange solution for sulphate reduction is one that combines both anionic and cationic resins. The paper presents the results from ion-exchange experiments by the synthetic ion-exchange resin and the AMBERLITE MB20 for $\mathrm{SO}_{4}{ }^{2-}$ removal from a model solution.

The efficiency of the AMBERLITE MB20 resin for $\mathrm{SO}_{4}{ }^{2-}$ removal from the model solution $\mathrm{H}_{2} \mathrm{SO}_{4}$ was higher than of the PUROLITE MB400, and its efficiency decreased with increasing the concentration of sulphates from $86.6 \%$ for the concentration $100 \mathrm{mg} / \mathrm{L}$ to $66.9 \%$ for the concertation $1000 \mathrm{mg} / \mathrm{L}$.

Key words: sulphates, ion-exchange, ion-exchange resin.

\section{Introduction}

Opencast mining activities have a serious environmental impact on soils and water streams, having generated millions of tons of sulphide-rich tailings [1]. Another most serious negative impact represents acid mine drainage (AMD), whether in the form of direct discharges or as a leachate from landfills [2].

Acid mine drainage (AMD) is a serious environmental problem resulting from the weathering of sulphide minerals, such as pyrite $\left(\mathrm{FeS}_{2}\right)$ and its polymorph marcasite $(\alpha-\mathrm{FeS})$. It is characterized by a low $p H$ value and high levels of sulphate and metals [3]. In the treatment of AMD, little attention has been focused on the mitigation of the dissolved sulphate; this may be attributed to its lower environmental risks and regulatory standards when compared to those for acidity and dissolved metals [4].
Sulphate is invariably present in groundwater, but its mobility in natural systems is restricted by its conversion to organo-sulphur compounds and by precipitation with some inorganic cations. This sulphate is discharged into water from geological strata with the gypsum and anhydrite content, from acid mine waters (AMD) and from industrial wastewater. Although sulphate's health effects are relatively short-term, it causes acute diarrhoea and dehydration at concentrations of $1000-1200 \mathrm{mg} / \mathrm{L}$ [4]. The selection of treatment processes was based on applicability to sulphate removal and the availability of data on sulphate removal and costs. Some processes have been proposed for AMD treatment applying ion-exchange resins [5].

The removal of sulphate ions constitutes one of the main challenges in the mining, metallurgical and chemical industries. Sulphate removal from aqueous streams is by far one of the most difficult and onerous tasks in these industries, and most of the existing processes are inefficient and costly [6]. 
There are several possibilities to remove sulphates from water. The most known are precipitation, reverse osmosis, nanofiltration and sorption including biosorption. In the biosorption study [7], seven types of bio-adsorbents were chosen: poplar, hornbeam, ash, oak, cherry, pine, and spruce wood sawdust. Hornbeam decreased the concentration of a sulphate at the value less than $0.5 \mathrm{mg} / \mathrm{L}$ in a solution of $\mathrm{CuSO}_{4}$ and $\mathrm{ZnSO}_{4}$, representing the efficiency of $99.0 \%$. In solutions of $\mathrm{FeSO}_{4}$, the sulphate was removed by ash and cherry with high efficiencies. Biological methods are also very popular. The treatment of AMD by SRB (sulphate-reducing bacteria) is based on the ability of SRB to reduce sulphates to hydrogen sulphide. In the study [8], using the cultivation of sulphate-reducing bacteria and a complete matrix with a nutrient medium, an about $40 \%$ efficiency of sulphate elimination (or reduction) and in the case of a medium without sulphates the $100 \%$ efficiency were achieved.

Ion-exchange is a very powerful technology to remove contamination from water and other solutions. Undesirable ions are replaced by others which do not contribute to the environment contamination. The method is technologically simple and enables an efficient removal of even traces of pollutants from solutions [9]. A wide range of materials is available for the ion-exchange treatment. These materials are available in a variety of forms, they have widely different chemical and physical properties and can be naturally occurring or synthetic. The type of the material to be used is selected based on its ability to remove undesirable ions and to control the $p H$ [10]. To minimize the disposal costs, in any process for the removal of pollutants from a liquid waste it is important to minimize the volume of the secondary waste to be conditioned and disposed of in a final repository. Environmental aspects are also very important, since the regulations on discharges are becoming increasingly more stringent. Highly selective synthetic ionexchangers play an important role in solving these problems [11].

This work studies the sulphate removal by two synthetic ion-exchange resins PUROLITE MB400 and AMBERLITETM MB20 which have not yet been tested for AMD treatment.

\section{Materials and methods}

For the study of $\mathrm{SO}_{4}{ }^{2-}$ ions removal from model solutions by the ion-exchange process, two inorganic ion-exchange resins - PUROLITE
MB400 (No. 1) and AMBERLITE MB20 (No. 2) were used.

PUROLITE MB400 (Fig. 1) is a high-quality resin mixture for the direct purification of water. It is suitable for use in regenerable or nonregenerable cartridges and in large ion-exchange units. The passage of water at recommended flow rates through the resin as supplied can achieve an almost complete reduction of the total dissolved solids. The residuals produce the average conductivity values of about $0.1 \mu \mathrm{s} / \mathrm{cm}$ for a major portion of the service run which may be extended depending upon the final water quality acceptable. The equivalent volumes of ultra-pure water may be obtained after regeneration, but only if sufficient regenerant quantities are employed to achieve the percentage conversion levels equivalent to those of the "as supplied" resin. The generally acceptable capacity and quality are obtained economically at a lower regeneration. The theoretical total combined capacity in the regenerated form is $0.55 \mathrm{eq} / \mathrm{L}$.

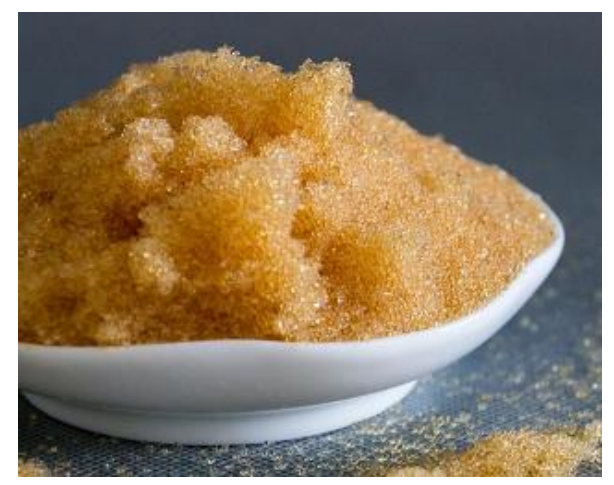

Fig. 1. PUROLITE MB400 resin.

The AMBERLITETM MB20 resin (Fig. 2) is an ionically equilibrated mixed bed resin. It is a fully regenerated, ready-to-use mixture of a strong acid cation-exchanger with a strong base type 1 anionexchanger. The AMBERLITE MB20 resin has been developed for the production of high-purity water. It can be used for all applications requiring totally demineralised water free of silica and of carbon dioxide.

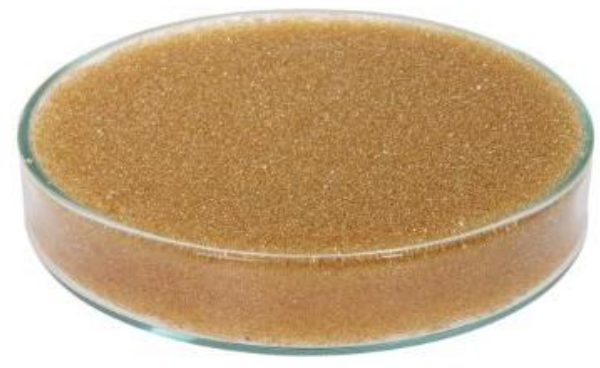

Fig. 2. AMBERLITE MB20 resin. 
Single synthetic solutions containing sulphate anions were prepared from sulphuric acid puriss. p.a. $93 \%$.

Working solutions were prepared by further dilution to the desired initial concentration of the sulphates. The initial $p H$ of each solution was not adjusted. The anion removal efficiency by the ionexchange process was tested at a laboratory temperature $\left(23 \pm 0.2{ }^{\circ} \mathrm{C}\right)$ under static conditions.

$1 \mathrm{~g}$ of resins No. 1 and $1 \mathrm{~g}$ No. 2 were mixed with $100 \mathrm{~mL}$ of each solution. After 24 hours of reaction the resins were removed by filtration through a laboratory filter paper for the qualitative analysis. The concentrations of ions before and after the experiments were determined in filtrates by the X-ray fluorescence method, Spectra iQ II (Ametek, Germany). The $p H$ values were determined with a $p H$ meter inoLab $\mathrm{pH} 730$ (WTW, Germany). All data are presented as the mean \pm SD of triplicate results.

The percentage of efficiency (\%) was calculated using the following equation:

$$
\text { Efficiency }=\frac{\left(C_{0}-C_{e}\right)}{C_{0}} \times 100 \% \text {; }
$$

where $C_{0}-$ initial concentration, $\mathrm{mg} / \mathrm{L} ; C_{e}-$ concentration after sorption, $\mathrm{mg} / \mathrm{L}$.

\section{Results and discussion}

The initial and residual concentrations of sulphate removal by resin No. 1 from model solutions are presented in Table 1.

Table 1. The initial concentration of $\mathrm{SO}_{4}{ }^{2-}$ and its concentration after $24 \mathrm{~h}$ of contact with the PUROLITE MB400 resin; $\mathrm{H}_{2} \mathrm{SO}_{4}$ solutions; batching $1 \mathrm{~g} / 100 \mathrm{~mL}$

\begin{tabular}{|l|c|c|c|}
\hline & \multicolumn{3}{|c|}{ Concentration of $\mathrm{SO}_{4}{ }^{2-}, \mathrm{mg} / \mathrm{L}$} \\
\hline Initial & 100 & 500 & 1000 \\
\hline $\begin{array}{l}\text { After 24 } \\
\text { hours of } \\
\text { contact }\end{array}$ & $25.4 \pm 3.3$ & $84.9 \pm 7.1$ & $519.7 \pm 17.4$ \\
\hline
\end{tabular}

The efficiency of the PUROLITE MB400 resin for sulphate removal from the model solution $\mathrm{H}_{2} \mathrm{SO}_{4}$ was $74.6 \%$ for the concentration $100 \mathrm{mg} / \mathrm{L}$, $83.2 \%$ for the concentration $500 \mathrm{mg} / \mathrm{L}$ and 48.03 $\%$ for the concertation $1000 \mathrm{mg} / \mathrm{L}$.

The initial and the residual concentrations of sulphate removal by resin No. 2 from model solutions are presented in Table 2.
Table 2. The initial concentration of $\mathrm{SO}_{4}{ }^{2-}$ and its concentration after $24 \mathrm{~h}$ of contact with the AMBERLITE MB20 resin; $\mathrm{H}_{2} \mathrm{SO}_{4}$ solutions; batching $1 \mathrm{~g} / 100 \mathrm{~mL}$

\begin{tabular}{|l|c|c|c|}
\hline & \multicolumn{3}{|c|}{ Concentration of $\mathrm{SO}_{4}{ }^{2-}, \mathrm{mg} / \mathrm{L}$} \\
\hline Initial & 100 & 500 & 1000 \\
\hline $\begin{array}{l}\text { After 24 } \\
\text { hours of } \\
\text { contact }\end{array}$ & $13.4 \pm 1.9$ & $67.1 \pm 7.8$ & $330.8 \pm 12.3$ \\
\hline
\end{tabular}

The efficiency of the AMBERLITE MB20 resin for $\mathrm{SO}_{4}{ }^{2-}$ removal from the model solution $\mathrm{H}_{2} \mathrm{SO}_{4}$ was $86.6 \%$ for the concentration $100 \mathrm{mg} / \mathrm{L}$, $85.5 \%$ for the concentration $500 \mathrm{mg} / \mathrm{L}$ and $66.9 \%$ for the concertation $1000 \mathrm{mg} / \mathrm{L}$.

One can see that the ion-exchange resin AMBERLITE MB20 seems to be more effective for sulphate removal in these acidic solutions. A comparison of removal efficiencies is presented in Fig. 3.

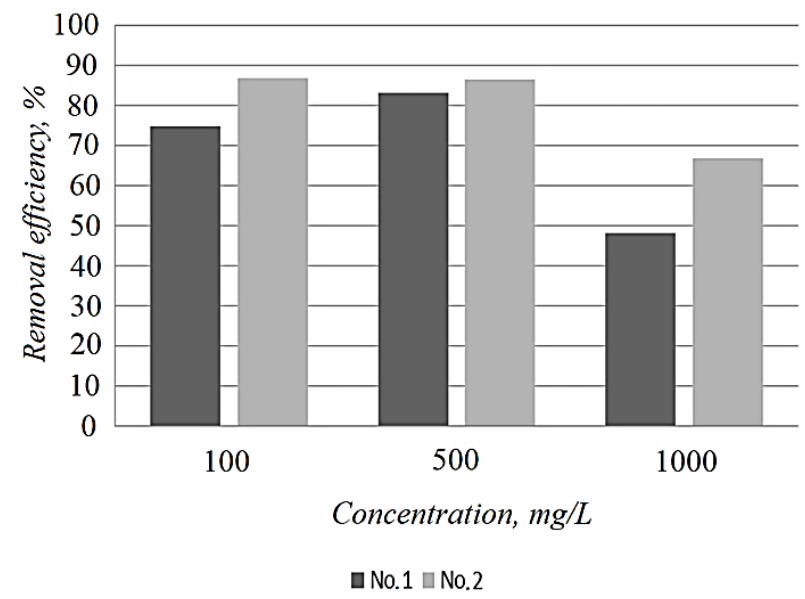

Fig. 3. Comparison of removal efficiencies.

The initial and the final $p H$ values after the ion-exchange process of the $\mathrm{H}_{2} \mathrm{SO}_{4}$ solution are presented in Tables 3 and 4 . One can see that both adsorbents caused an increase of the $p H$ values in these solutions.

Table 3. The initial $p H$ values and its values after $24 \mathrm{~h}$ of contact with the PUROLITE MB 400 resin

\begin{tabular}{|l|c|c|c|}
\hline $\begin{array}{l}\text { Initial } \\
\text { concentration } \\
\text { of } \mathrm{SO}_{4}^{2-}, \mathrm{mg} / \mathrm{L}\end{array}$ & 100 & 500 & 1000 \\
\hline Initial $p H$ & 2.45 & 1.95 & 1.54 \\
\hline $\begin{array}{l}p H \text { after } 24 \text { hours } \\
\text { of contact }\end{array}$ & $6.42 \pm 0.3$ & $2.96 \pm 0.4$ & $1.98 \pm 0.3$ \\
\hline
\end{tabular}


Table 4. The initial $p H$ values and the $p H$ values after $24 \mathrm{~h}$ of contact with the AMBERLITE MB20 resin

\begin{tabular}{|l|c|c|c|}
\hline $\begin{array}{l}\text { Initial } \\
\text { concentration } \\
\text { of } \mathrm{SO}_{4}^{2-}, \mathrm{mg} / \mathrm{L}\end{array}$ & 100 & 500 & 1000 \\
\hline Initial $p H$ & 2.45 & 1.95 & 1.54 \\
\hline $\begin{array}{l}p H \text { after } 24 \text { hours } \\
\text { of contact }\end{array}$ & $7.88 \pm 0.4$ & $3.5 \pm 0.5$ & $2.11 \pm 0.2$ \\
\hline
\end{tabular}

The $p H$ is one of the most important parameters to control the uptake of sulphates from aqueous solutions. In both solutions the ionexchange resins PUROLITE MB400 and AMBERLITE MB20 caused an increase of the initial $p H$ values (see Tables 3 and 4).

The increase of $p H$ was caused by the $\mathrm{OH}^{-}$ions exchange from the resin with sulphate ions and their release into the solution.

According to the presented results, AMBERLITE MB20 will be used as a potential resin for sulphate removal under dynamic conditions using a column setup with the aim of its using for a partial acid mine drainage treatment.

An appropriate combination of sorption and ion-exchange materials in this case has a high potential for a complex treatment of AMD in real conditions.

\section{Conclusions}

1. This study has shown the possibility of using two synthetic ion-exchange resins PUROLITE MB400 and AMBERLITE MB20 for $\mathrm{SO}_{4}{ }^{2-}$ removal from a model acidic solution.

2. In general, AMBERLITE MB20 exhibits better ion-exchange properties than PUROLITE MB400.

3. The decrease of the $\mathrm{SO}_{4}{ }^{2-}$ concentration using AMBERLITE MB20 is about $86.6 \%, 85.5 \%$ and $66.9 \%$ for solutions containing $\mathrm{SO}_{4}{ }^{2-}$ ions at the initial concentration of $100 \mathrm{mg} / \mathrm{L}$, $500 \mathrm{mg} / \mathrm{L}$ and $1000 \mathrm{mg} / \mathrm{L}$, respectively.

4. The obtained results show that both types of ion-exchange resins could be used for sulphate removal in acidic conditions and for AMD treatment.

\section{Acknowledgements}

This work has been supported by the Slovak Grant Agency for Science (Grant No. 1/0563/15).

\section{References}

1. Bhattacharya A., Routh J., Jacks G., Bhattacharya P., Mörth M. Environmental assessment of abandoned mine tailings in Adak, Västerbotten district (northern Sweden) // Applied Geochemistry. 2006. Vol. 21. N 10. P. 1760-1780. https://doi.org/10.1016/j.apgeochem.2006.06.011

2. Gündogan R., Acemioglu B., Hakki Alma M. Copper (II) adsorption from aqueous solution by herbaceous peat // Journal of Colloid and Interface Science. 2004. Vol. 269. N 2. P. 303-309. https://doi.org/10.1016/S0021-9797(03)00762-8

3. Šlesárová A., Zeman J., Kušnierová M. Geochemical characteristics of acid mine drainage at the Smolník deposit (Slovak republic) // IMWA Symposium 2007: Water in Mining Environments, Cagliari: IMWA. P. 467-371.

4. Kupka D., Cucak V. Nitrate, sulphate and phosphate removal from groundwater by anion exchange resins // Podzemná voda. 2013. Vol. 19. N 1. P. 43-51.

5. Damaris G., Versiane A. L. Studies of sulfate ions removal by the polyacrylic anion exchange resin Amberlite IRA458: batch and fixed-bed column studies // Mine Water - Managing the Challenges. 2011. Vol. 11. P. 337-342.

6. Silva R., Cadorin L., Rubio J. Sulphate ions removal from an aqueous solution: I. Coprecipitation with hydrolysed aluminum-bearing salts // Minerals Engineering. 2010. Vol. 23. N 15. P. $1220-1226$ https://doi.org/10.1016/j.mineng.2010.08.016

7. Demcak S., Balintova M., Pavlikova P. Study of sorption properties of various wood sawdust for sulphate removal // Proceedings of international scientific conference "People, Buildings and Environment”. Luhačovice, Czech Republic, 2016. Vol. 4. P. 206-211.

8. Luptáková A., Kotuličova I., Mačingová E., Jenčárová J. Bacterial elimination of sulphates from mine waters // Chemical Engineering Transactions. 2013. Vol 35. P. 853-858. https://doi.org/10.3303/CET1335142

9. Dabrowski A., Hubicki Z., Podkościelny P., Robens E. Selective removal of the heavy metal ions from waters and industrial wastewaters by ion-exchange method // Chemosphere. 2004. Vol. 56. N 2. P. 91-106.

https://doi.org/10.1016/j.chemosphere.2004.03.006

10. Application of ion exchange processes for the treatment of radioactive waste and management of spent ion exchangers. Technical reports series No. 408. Vienna, International atomic energy agency, 2002. $115 \mathrm{p}$.

11. Hussain A., Al-Othmany D. Treatment and conditioning of spent ion exchange resin from nuclear power plant // Advances in Physics Theories and Applications. 2013. Vol. 15. P. 79 89. 
M. Holub, P. Pavlikova, M. Balintova, M. Smolakova

JONŲ MAINŲ DERVŲ PRITAIKYMAS

SULFATO JONAMS PAŠALINTI IŠ RŪGŠČIŲ TIRPALŲ

\section{S a n t r a u k a}

Sulfato jonų pašalinimas iš užteršto vandens (nuotekų) yra aplinkosaugos problema, su kuria susiduria ịvairios pramonès šakos: kasyba (kalnakasyba), naftos ar metalurgijos pramonè. Labiausiai paplitę būdai neveiksmingi (neefektyvūs) ir ekonomiškai igyvendinami (perspektyvūs), ypač valant rūgščius telkinius, kurių mažas $p H$ ir didelès sunkiųų metalu ir sulfatų koncentracijos. Šiame darbe pateikiama, kad jonu mainu metodas, kuris yra vienas labiausiai paplitusių apdorojimo būdų, gali būti panaudotas rūgščių nuotekoms valyti.

Vykstant jonų mainams (metodas - tai labai efektyvi technologija), vienas ar keli nepageidaujami teršalai pašalinami iš užteršto vandens (nuotekų), sukeičiant juos su kitomis medžiagomis. Sulfatų kiekiui sumažinti galima kartu naudoti anijonines ir katijonines dervas. Darbe sulfato jonams pašalinti iš modelinio $\mathrm{H}_{2} \mathrm{SO}_{4}$ tirpalo buvo panaudotos dvi sintetinès jonų mainu dervos PUROLITE MB400 ir AMBERLITE MB20. Gauti rezultatai parode, kad AMBERLITE MB20 derva yra veiksmingesnè šalinant sulfato jonus iš modelinio rūgštaus tirpalo nei PUROLITE MB400 derva. Tačiau sulfato jonų koncentracijai padidèjus nuo $100 \mathrm{mg} / \mathrm{l} \mathrm{iki} 1000 \mathrm{mg} / \mathrm{l}$, šis efektyvumas sumažeja nuo $86,6 \%$ iki $66,9 \%$.

Reikšminiai žodžiai: sulfatai, jonų mainai, jonų mainų derva. 